DOI: https://doi.org/10.32839/2304-5809/2021-7-95-21

УДК 2-4

Якуніна К.I.

Національний університет «Острозька академія»

\title{
СОЦІАЛЬНО-ПСИХОЛОГІЧНІ АСПЕКТИ РЕЛІГІЙНОСТІ
}

\begin{abstract}
Анотація. Дослідження релігійності, зацікавлення в щій темі багатьох дослідників зумовлена прагненням до кращого розуміння людської сутності - ще одного кроку на шляху до осягнення світу і ролі та місця в ньому людини. Намагаючись віднайти відповіді, більшість науковців прагнуть до дослідження окремих аспектів тіеї чи іншої проблеми, але досить часто лише у взаемозв'язку можливе осягнення істинної суті питання. Саме тому, метою дослідження є аналіз соціально-психологічних передумов релігійності. Людська життедіяльність, у будь-яких їі проявах, зумовлюе постійні відношення одного явища до іншого, показуючи всі тонкощі їх існування. Простеживши еволюцію наукових поглядів на релігійність та їі компоненти, можна говорити не лише про соціальну прояв релігії та релігійність населення як показника одухотвореності чи моральності суспільства, а й зауважувати що, релігійність відображає певний рівень еманації, надприродніх пошуків людини. Релігійність стає невід'ємним виміром людського буття і залишаеться безумовною потребою людини, зокрема потребою в її духовному світі.
\end{abstract}

Ключові слова: релігійність, релігія, духовність, сенс життя, духовні пошуки людини.

Yakunina Kateryna

National University of Ostroh Academy

\section{SOCIAL AND PSYCHOLOGICAL ASPECTS OF RELIGIOUSNESS}

Summary. Research of religiousness, personal interest in this theme of many researchers predefined by aspiring to the best understanding of human essence - another step on a way to understanding of the world and role and place in him man. Trying to find answers, most research workers aspire the separate aspects of that or other problem to research, but often enough only in intercommunication possible understanding of veritable essence of question. For this reason, a research purpose is an analysis of social and psychological pre-conditions of religiousness. Human vital functions, in any its displays, predetermine permanent attitudes of one phenomenon toward other, showing all subtleties of their existence. Tracing the evolution of scientific looks to the religiousness and its components, it is possible to talk not only about social the display of religion and religiousness of population as an index of spirituality or morality of society but also to notice that, a religiousness is represented by the certain level of emanation, supernatural searches of man. Religiousness becomes the inalienable measuring of human life and remains the absolute necessity of man, in particular by a requirement in its spiritual world. One of urgent tasks of modern society the problem of search of spiritual basis becomes. Consequently, religiousness as display of higher belonging of all-embracing love, allows to feel emanation of transcendentally and become firmly established in own attitude toward surrounding reality. The internal displays of religiousness and psychical processes which accompany its influence on a man allow not only best to the integration in society but also internal to harmony and self growing. Trying to escape from society, we more frequent all escape from itself, aiming to understand not only own desires but also nature. A man at all perfection and defects always aspires to the ideal, searching in him not only answers for problem questions but also estimation of own essence, although more frequent all and not realized.

Keywords: religiousness, religion, spirituality, sense of life, spiritual searches of man.

Постановка проблеми. Одним із нагальних

1 завдань сучасного суспільства стає проблема пошуку духовних орієнтирів. У цьому контексті актуалізуеться гостра потреба у формуванні нової парадигми світосприйняття, яка б розширювала світогляд людини від ращіонально-прагматичної зацікавленості до духовно-трансцендентних сенсів існування. Розвиток сучасного сощумму, який має збагачуватися, долаючи наслідки довготривалої духовної кризи, актуалізуеться необхідність імплементації в свідомість наших сучасників загальнолюдських цінностей, які становлять морально-етичну основу, гармонізовуючи внутрішній світ людини.

Розвиток українського суспільства як демократичної, відкритої системи, що долає ідеологічні штампи минулого, значною мірою залежить від глибини теоретичного осмислення явищ і процесів його багатогранної, різновекторної, суперечливої реальності, в тому числі й духовної. Одним із виразників останньої є релігійність як опредмечення, об'єктивізація цього надіндивідуального феномена в свідомості, поведінці, способі життя окремих індивідів, які входять до певних релігійних спільнот та творчість як своєрідний дар людини, внутрішне споглядання, істинне осягнення всього чистого і неповторного.

Аналіз останніх досліджень та публікацій. Проблема "релігійності» досліджувалась багатьма вченими таких галузь знань як фрілософрія, релігієзнавство, психологія, літературознавство, соціологія. Вона досліджувалась як у сырері одніеї науки, так і у симбіозі з іншими. Своєрідність розгляду релігієзнавчих проблем полягає у безпосередньому синтезі цього поняття 3 соціокультурними аспектами та канонічними особливостями. Окремі аспекти обраної та досліджуваної теми висвітлені у працях: Бодак В., Васільева О., Дудар Н., Предко О. та Яблокова I.

Ціль статті - аналіз сощіально-психологічних передумов та базису релігійності.

Виклад основного матеріалу. Релігійність - одне 3 важливих понять сощіологї релігії, що характеризуе якісну і кількісну визначеність суб'єктивного засвоєння релігійних ідей, цінностей, норм та їхній вплив на поведінку, життедіяльність віруючих, релігійної спільноти, її можна розглядати як ціннісножиттеву орієнтацію, суб'єктивну якість свідомості індивіда, його внутрішню здатність до ре- 
алізащї релігійних установок. Ступінь релігійності характеризуе рівень засвоєння індивідом, групою релігійних ідей, норм, цінностей, тобто рівень інтенсивності релігійних ознак [3, с. 110]. Намагаючись систематизувати те чи інше знання, ми прагнемо до розуміння його глибинних проявів. Розглядаючи релігійність як психо-соціологічний френомен, ми не лише прагнемо зрозуміти механізми його прояву у суспільстві, а й віднайти внутрішню закономірність у об'ектів ії фрункціонування.

Релігія, торкаючись глибин людської душі й створюючи умови для контакту 3 надприродною дійсністю, виконуе багато важливих фрункцій у людській особистості. Серед психологів і психіатрів нині, як i раніше, панують різні погляди на цю проблему, але, так чи інакше, усі вони погоджуються в одному, що релігійність - це виняткове явище в житті людини. Зате вони по-різному оцінюють іï значимість, е навіть такі, що, визначаючи психологічну значимість релігійності, водночас приписують їй негативні фонкції, а тому деколи розпочинають боротьбу за «визволення людини від релігійних міфрів і неврастеній» [5, с. 227]. Типовий їх представник З.Фрейд - писав: «Боги виконують потрійну роль: заклинання зі страху природи; примирення людини 3 жорстокістю долі, яка найвиразніше виявлена в смерті; винагородження терпінь, що їх суспільне життя поклало на людину» [7, с. 342].

В працях 3 релігієзнавства рідко піднімалося питання про вплив психофрізіологічних процесів на розвиток релігійності. Вважається, що ці процеси є причинами розвитку чи відсутності релігійності у людини, але на їх основі можна зробити цікаві висновки. Тому сфрормулюємо декілька основоположень, на основі яких побудована запропонована схема розвитку релігійності:

1. Етап дитинства є принципово важливим для аналізу розвитку релігійності, оскільки на цьому етапі закладаються усі основні вміння, схильності, навички та моделі поведінки, які розвиватимуться в міру дорослішання. Під дитинством тут розуміємо етап від народження до 14 років (Перинатальні переживання не включені, оскільки не існуе підтверджених теорій щодо цього).

2. На інтерпретацію більш пізньої інформації накладають відбиток перші або ранні відчуття, наприклад, люди можуть надавати значення важливим подіям у житті, з точки зору релігійних переконань, які були прищеплені їм сім'єю в дитинстві. Людина не обов'язково свідомо приймає рішення про релігійну орієнтацію, відносячи себе до конфесії тому, що постійно виконуе практики, традиційні для даного віросповідання. Теза про послідовність та несвідомість деяких переживань є класичною для психоаналізу і досі незаперечною.

3. Згідно з біогенетичним законом рекапітуляції Геккеля, застосованого до функцій головного мозку, онтогенез повторюе фрілогенез, причому відтворюе його з обернено-пропорційною швидкістю. Тобто розвиток індивідуальної релігійності дитини тією чи іншою мірою повторюе процес формування релігійності сощіуму, в якому вона виховуеться.

4. Індивідуальна та соціальна релігійність це два взаємодоповняльні феномени, неможливі один без одного. Між ними існує постійний динамічний зв'язок [4, с. 13$]$.

До найважливіших природних потреб людини, у межах яких фрункціонує релігійність, належать пізнавальні, емоційні та суспільні потреби. Значення релігії для емоційних потреб людини - найпершочерговіше у відношенні до потреби безпеки. Потреба безпеки формується першою і найфрундаментальніше визначає буття людини в світі, а їі заспокоення творить у людині схильність до довіри (так званої прадовіри). Релігія гарантуе почуття безпеки, переконуе в перемозі добра над злом, життя над смертю. Таким чином два основні джерела неспокою й почуття загрози - зло та смерть зводяться до мінімуму або й зовсім втрачають свою силу. Почуття загрози, тобто брак почуття безпеки, викликає відчуття хаосу. Релігія не лише допомагає вийти 3 цього стану, пропонуючи певні категорії розуміння дійсності, але й приводить людину до абсолютного й незмінного Авторитету, встановлюючи нове почуття вкоріненості. Релігії схиляють до думки, що існуе хтось близький, хто може розв'язати проблему загрози почуттю безпеки. Релігія навчає, що можна мати безпосередній контакт з незмінним Богом. Це приносить людині почуття стабільності. Бог довіряе людині, шанує їі гідність, перемагає минущість, звільняе від вини, а за допомогою морального права - допомагає зорієнтуватись у складних ситуаціях [8, с. 10].

Відомо, що недостатне відчуття безпеки й пов'язані з цим побоювання стають причиною психічних проблем, наприклад неврастенії. Обмежуючи й раціоналізуючи загрозу, релігія може здійснювати лікувальний вплив. Напруження i страх виникають із розбіжностей між світами можливостей і прагнень людини, що виявляеться у втраті почуття власної тотожності. Власна тотожність розвивається в контексті непевності стосовно сприйняття нас визначними особами. Беручи до уваги релігійну перспективу, слід відмітити, що релігійна самоідентиорікація у кожної окремої особи пов'язана з усвідомленням способу сприйняття іï Богом, тобто з питанням: що Бог думає про мене? Основний досвід - це прийняття істини, що Христос приймає особу в сталий і незмінний спосіб. Незмінна акцепція Богом, однак, не оберігає людину від різних труднощів. Виникають вони найперше у зв'язку з руйнуванням попередньої самоідентифікації та створенням нового способу буття в мінливих обставинах [6, с. 222].

Природа людини складна і багатогранна структура, яка потребуе постійного самовдосконалення та саморозвитку. Живучи у суспільстві і діючи у замкненій системі, ми найбільше прагнемо до усамітнення та до визнання нашої неповторності. Самоактуалізація як необхідність робити те, що людині доступно, й дозрівання до величі власної природи через реалізацію особових потенщій, $е$ необхідною для будь-якого людського поступу. Зв'язок релігії із самоактуалізацією для багатьох людей визначає спосіб реалізації своїх талантів. Християнська доктрина твердить, що все, що є в людини, їй дароване, а сама вона є лише розпорядником, який зобов'язаний відзвітуватися за весь час користування. Самоакгуалізація, позбавлена такої глибокої мотивації, яку приносить релігія, залишиться лише голослівним лозунгом. Тому, як наголошують психологи-гуманісти, у людини існує потреба трансцендентності, тобто перевищення свого власного “Я", полягае вона в сприйманні себе й інших значимих особистостей, а також людського життя загалом, не у вигляді засобу, а мети [5, с. 87]. Усі гуманістичні 
й автентичні релігії звертаються до людини з закликом піднятися над тваринним рівнем своєї природи й реалізувати надприродні (трансцендентні) потреби. Поняття трансцендентності в релігійному контексті має принаймні подвійне значення. Поперше, відноситься до специорічних властивостей людської психіки, завдяки яких боронитися від пустоти. Ця порожнеча, що їі може зазнати людина, буває принаймні двох типів. Так, буває порожнеча аксіологічна, коли дана особа не сприймає проблеми цінностей і не бачить, які категорії поведінки пов'язані з етичним оцінюванням, а які такій оцінці не підлягають. Іншим фундаментальним типом пустоти є невміння іменувати оточуючі явища, тобто так звана інтелектуальна порожнеча, коли людина не дозріла до спроможності робити порівняння, класифрікації, структурний аналіз та означувати явища й предмети оточуючого світу.

3 цим пов'язана цікава, хоча й непроста, проблема, яким чином відкрити для людей можливість релігійно поглиблюватися, незважаючи на деякі інтелектуальні обмеження. Адже зрозуміло, що релігійність не є привілеєм вибраних осіб з особливо високим рівнем інтелекту і фрункціонуе також серед людей менш розвинутих розумово. Тим не менше інтелект має своє особливе значення в розумінні й розвитку релігійного акту, наприклад, у дослідженнях релігійних та інтелектуальних позищій молоді виявлено, що чим вищий рівень інтелекту, тим кращі у молодих людей релігійні знання, частіше й інтенсивніше виконання релігійних обрядів і послідовніше застосування в житті моральних норм, пов'язаних з релігією [1, с. 202]. Однак не можна твердити про зворотну залежність, тобто, що релігійність принципово впливає на розвиток інтелекту й інтелігентності. Правдоподібною була б теза, що рівень і тип інтелекту визначає спосіб фрункціонування релігійності в людській особистості. Але також зовсім не обов'язково видатний інтелектуал буде розуміти релігію саме як систему істин; він може бачити в ній схильність до благородних переживань, відчуття близькості Бога тощо. Тут проявляеться принцип взаємного доповнення інтелекту й емоційної релігійності.

Будучи критерієм релігії, релігійність все ж $є$ суб,єктивною та двоякою, адже в будь-якому разі їй притаманна колективна якість та властивість психічного френомену кожного окремого індивіда [2, с. 12]. Для пересічної людини цей специорічний стан душі є проявом внутрішніх поривань, які є результатом синтезу їі власних та колективних вірувань. Але сам феномен має не лише якості культової діяльності, а й внутрішньої еманації особистості та певної ідеальної субстанції. Релігійність, базована на любові, дозволяе уникнути небезпеки надмірного підкреслення та абсолютизації власного Я й досягнути певної свободи у світі людських норм і обов'язків. Саме розуміння релігійності як індивідуальної якості кожної особи дозволяє виявити не лише особливості становлення цього явища, а й осягнути істинне значення його для кожного індивіда. Адже саме релігійність дозволяє осягнути реалії, які не підвладні не лише розуму, а й "інтелекту" людства; вона дозволяе оперувати абстрактними поняттями психології в реальності і осягати істину сутність всезагальних поривань та власні бажання, даючи надію і впевненість у майбутне.

Висновки і пропозиції. Отже, релігійність як вияв вищої приналежності всеохоплюючої любові, дозволяе відчути еманацію трансендендентного та утвердитись у власному ставленні до оточуючої дійсності. Внутрішні прояви релігійності та психічні процеси, що супроводжують ії вплив на людину, дозволяють не лише кращій інтеграції у суспільство, а й внутрішній гармонії та саморозвитку. Намагаючись втекти від соціуму, ми найчастіше втікаємо від себе, прагнучи зрозуміти не лише власні бажання, а й природу. Людина при всій своїй досконалості та вадах завжди прагне до ідеалу, шукаючи в ньому не лише відповіді на проблемні питання, а й оцінку власної сутності, хоча найчастіше і не усвідомлено.

\section{Список літератури:}

1. Бодак В. Релігія і культура: взаємовплив і взаємодія. Київ : Коло, 2005. 305 с.

2. Васільева О.С. Релігія в контексті духовного світу особистості : автореферат дис. канд. фрілос. наук. Київ, 2006. 24 с.

3. Введение в общее религиоведения : Учебник / Под ред. И. Яблокова. Москва : Книжный дом «Университет», 2001. 576 c.

4. Дудар Н.П. Релігійність в українському соціумі: детермінанти і характеристика сучасного стану : Авторедерат дис. канд. соціол. наук. Київ, 2002. 33 с.

5. Предко О. Психологія релігії: історія, теорія, релігійні виміри. Київ : Центр навчальної літератури, 2005.278 с.

6. Психологія: з викладом основ психології релігії / Під ред. о. Юзефа Макселона. Львів : Свічадо, 1998.320 с.

7. Релігієзнавчий словник / За ред. А. Колодного, Б. Ломовика. Київ : Четверта хвиля, 1996. 392 с.

8. Сандига О. Соціальна творчість: Пітер Бергер, Томас Лукман та Карл Попер. Філособбська дулка. 1999 . № 5. C. $151-157$.

\section{References:}

1. Bodak V. (2005). Religia I kultura: vzaiemovpliv I vzaiemodia [Religion and culture: co-operation]. Kyiv: Kolo, 305 p.

2. Vasileva O.S. (2006). Religia v konteksti duhovnogo svitu osobistosti [Religion is in the context of the spiritual world of personality], $24 \mathrm{p}$.

3. Yablokov I. (2001) Vvedenie v obshchee religiovedenie [Introduction to general religious stadies]. Moscow: Knyzhnyi dom «Unyversytet», $576 \mathrm{p}$.

4. Dudar N.P. (2002). Religiynist v ukrainskomu sociumi: determinanti I harakteristika suchasnogo stanu [Religiousness is in Ukrainian society: determinants and description of the modern state], $33 \mathrm{p}$.

5. Predko O. (2005). Psihologia religii: istoriya, teoriya, religiyni vimiri [Psychology of religion: history, theory, religious measurings]. Kyiv: Tsentr navchalnoi literatury, $278 \mathrm{p}$.

6. Yuzef Makselon (1998) Psihologia: z vikladom osnov psihologii religii [Psychology: with exposition of bases of psychology of religion]. Lviv: Svichado, 320 p.

7. Kolodniy A., Lomovik B. (1996) Religiyeznavchiy slovnik [Dictionary of religious stadies]. Kyiv: Chetverta khvylia, 392 p.

8. Sandiga O. (1999). Socialna tvorchist: Piter Berger, Tomas Lukman, Karl Poper [Social creation: Peter Berger, Thomas Lukman and Charles Poper]. Filosofska dumka, vol. 5, pp. 151-157. 